\title{
Tourist's Group Knowledge Representation and the Role of E-Wom for the Choice of Tourist Destination
}

\author{
By Francesca Di Virgilio* \\ Loredana Di Pietro ${ }^{\dagger}$
}

\begin{abstract}
This paper provides a conceptual representation to explore the tourist's group knowledge investigating the influence of group variables and the role of e-word-of-mouth communication on decision making process. Augmenting organizational behavior approach we illustrate a conceptual proposal for improving the current tourist's knowledge representation through integration of one important level of analysis: the group. Despite, we integrates also the constructs e-word-of-mouth communication in the conceptual proposal. The findings of this research support the development of tourism marketing and communication strategies focused on the online contexts as factors capable of influencing tourist's behaviour in a more efficient way. This research does not focus on a specific tourist's destinations, thus the presence of different destinations may affect consumers in different ways, according to their involvement towards to a particular destination. This study contributes to deepening the scientific debate on the tourist's destinations. In the past literature, many aspects of tourist behavior have been neglected. One of these aspects is exactly the study of tourist's group behavior that is the original focus of this paper. Keywords: group's dynamics, tourist's group knowledge, decision making process, e-wom.
\end{abstract}

\section{Introduction}

Knowledge has the highest value, the most human contribution, the greatest relevance to decisions and actions; it has sense of power and the greatest dependence on a specific situation or context (Poston \& Speier, 2005; Tanriverdi, 2005; Wasko \& Faraj, 2005). Knowledge must exist before information can be formulated and before data can be processed and measured to form information. As such, raw data does not exist if thought or knowledge processes that lead to its identification and collection have already influenced even the most elementary part of data. It is argued that knowledge which exists, when articulated, verbalized, and structured, becomes information

*Assistant Professor, University of Molise, Italy.

†Post Doctor Fellow, University of Molise, Italy. 
which in turn, when assigned a fixed representation and standard interpretation, becomes measurable data (Alavi \& Leidner, 2001).

One of the reasons that knowledge is such a difficult concept is because this process is recursive, expanding and often discontinuous. According to Grover and Davenport (2001), many cycles of generation, codification and transfer are concurrently occurring in businesses. These cycles feed on each other. Knowledge interacts with information to increase the state space of possibilities and provide new information, which can then facilitate generation of new knowledge. The knowledge process acts on information to create new information that allows for greater possibilities to fulfil old or possibly new organizational needs. This process is often discontinuous, where new needs and their fulfilment mechanism could be created.

A significant implication of this view of knowledge is that the advances in web-based technologies, as well as the increasing interest in social networking systems prompt industry to reconsider the way for individuals to arrive at the same understanding of information; they must share the same knowledge framework (Ogunseye et al., 2011; Vuori \& Okkonen, 2012). These technologies support collaborative writing (e.g., wikis), content sharing (e.g., text, video, and images), social networking (e.g., Facebook, Twitter), social bookmarking (e.g., ratings, tagging), and syndication (e.g., RSS feeds) (O'Reilly, 2005; Menkhoff et al., 2011). These new technologies increase the potentiality of the web sites, by combining interactive functions.

In particular, social networks are becoming an efficient tool for IT-based business, by providing several services for tourism market. Through the social network, the way people plan for, buy and consume tourist products and services (Buhalis \& Law, 2008; Papanis \& Kitrinou, 2011), dramatically change the role of tourism intermediaries (Kracht \& Wang, 2009). Tourists can post their thoughts and opinions about holidays and tourism experiences, by making them available to the global community of Internet users (Dellarocas, 2003).

The features this information sharing process include the increasing use of social network to link actors across market boundaries, to share common knowledge (Cheng, 2010), and to create new connections among users and between firm and clients (Boyd \& Ellison, 2007). In fact, these virtual and free spaces play an important role in information diffusion among tourists capable of influencing their behavioural intentions (de Valck et al., 2009; Pantano \& Servidio, 2011).

In this scenario, this research explores the role of e-wom in a conceptual representation of tourist's group knowledge. This paper is organized as follows: in the next section, we discuss the frame structure approach to a theoretical representation for explaining tourist decision making process, where the theory is grounded in dynamics of the tourists constituting the group in question and following we question about the possible role of e-wom on tourist decision making process. At the end directions for future researches are suggested. 


\section{Literature Review}

\section{Group Dynamics and Decision Making Process}

In this point of view, we discuss that knowledge of the tourist's group lead to richer content and can help explain why tourists do what they do. In this scenario, group dynamics became key factors to understand a tourist's group. The term "group dynamics" refers to the mechanisms of relationship that take place within a group (Stewart et al., 1999). In general, researchers have found group dynamics to be important for acquiring information (Gruenfeld et al., 1996), for disseminating useful knowledge (Schermerhorn et al., 2008), for solving complex problems (Rulke \& Galaskiewicz, 2000) and for influencing decision making process (Yoon et al., 2009).

The primary purpose of this paper is to explore group's dynamics that influence the decision making process of informal groups: trust; cohesiveness; diversity.

Researchers from organizational behaviour and management and related fields agree that trust has important organizational and group consequences (Mayer et al., 1995; Zaheer \& Venkatraman, 1995; Davis et al., 2000; Spreitzer \& Mishra, 2002). A foundation for this study is the Mayer et al. (1995) framework for trust. This model posits that trust is a form of beliefs about another party's ability, benevolence, and integrity. It's the willingness of a party to be vulnerable to the actions of another party based on the expectation that the other will perform a particular action important to the trust or, irrespective of the ability to monitor or control that other party (Mayer et al., 1995). Party can refer to a group, allowing the definition to be employed for our purposes. In this study we explore whether or not a group as a whole can exhibit trust. The trust literature provides considerable evidence that trusting relationships lead to greater knowledge exchange and to better decisions. When trust exists, people are more willing to give useful knowledge and are also more willing to listen and to absorb others' knowledge (Levin, 1999). By reducing the need to verify information, trust also makes knowledge transfer less costly. For example, Levin (1999) found that strong trusting ties usually helped improve knowledge transfer between scientists and engineers. Instead affect-based trust is typically found to be important in the context of social relationships for informal group of tourists. Therefore, trust plays a key role for customers' shopping decisions.

The nominal definition of cohesiveness is the degree to which members are attracted to and motivated to remain part of a group (Dirks \& Ferrin, 2001). Group cohesiveness is important because individuals in a cohesive group value their membership and make an effort to maintain positive relationships with other group members. Second, members are concerned about their group's activities and achievements. They tend to be more energetic in working on group activities, less likely to be absent, happier about performance success, and unhappier about failures than members of a less cohesive group. As a result, it is easier for cohesive groups to manage members and achieve goals. 
Dirks and Ferrin (2001) highlight the importance of cohesiveness for the success of knowledge transfer because it increases the effort in reconstructing the transferred information and in applying them in terms of knowledge.

Diversity is another group's dynamic. We can divide in two categories: demographic diversity and background diversity. The demographic diversity refers to the degree to which a unit (e.g. a working group or organization) is heterogeneous with respect to demographic attributes. Attributes classified as demographic generally include immutable characteristic such as age, gender and ethnicity; attributes that describe individuals' relationship with group, such as group position (leader, follower, etc.) (Lawrence, 1997; Shaw \& BarretPower, 1998; Jehn \& Bezrukova, 2004). Scholars examining diversity in groups have primarily focused on the consequences of demographic diversity for processes such as communication and decision making (Jehn \& Mannix, 2001). The consistently negative effects of demographic diversity on group processes are likely the result of heightened member emphasis on social categories rather than project-relevant information. Therefore, we posit that demographic diversity should not increase the value of intragroup knowledge and of decision making process. Background diversity relates to the different sets of task-relevant skills, knowledge, and abilities group members possess as a function of their educational backgrounds. Education is one of several sources of knowledge that contribute to one's expertise. Expertise provides group members a framework for considering what information is important to the task their group is to do, which in turn influences what information they attend to and incorporate into decisions (Bunderson \& Sutcliffe, 2002). Diversity of group members' educational backgrounds will determine how a group will use information and make decisions (Pelled et al., 1999).

Research has found also that the characteristics of prior knowledge possessed by group members and how information is distributed within the group affect the decision making process (Levine, 1999). The literature about groups also indicates that group decision making depends not only on information resources available to the group, but also on the processes or structures which groups use to exploit these resources. Stasser, Vaughan and Stewart (2000) further found that as a piece of information was distributed across more individuals within the group, the retrieval of this information became more likely and thus facilitated group decision making.

Management theorists and researchers agree that decision making represents one of the most common and most crucial of all group activities (Maznevski, 1994; West et al., 1997; Postmes et al., 2001). When decision making is conceived as a cycle of interactions between individual members such that each person is seen to give off and to receive attempts to influence others, the perspective is an interpersonal one. Here, group members act or react in coordinated ways, but no notions of collective concepts are incorporated. Rather, analyses are confined to individual characteristics (e.g., personal beliefs) and individual actions. By contrast, when group decision making is seen as a social process of joint formation of goals and intentions, the perspective is a plural subject one. Here members jointly construct mutual 
understandings and shared volitional commitments to make a group decision and consciously come to see their actions in this way. Such collective concepts as group or social identity become a central variable in knowledge management. Our research is based on this approach. We can apply the decision making process to a group of tourists because every day tourist's groups make decisions about the choice of tourist destination.

The process of decision making of a tourist's group tends to follow some steps (Franco et al., 2010). The first step is identifying the tourist destination. This step isn't always as easy as it sounds. Members of groups of tourists could distort, omit, ignore, and/or discount information around them that provides important cues regarding the existence of service need. This, of course, is problematic. After all, a need cannot be satisfied if it is never recognized. Next stage is to individuate possible tourist destination to satisfy a need. Because all these possibilities may not be equally feasible, the successive step calls for evaluating alternative destinations. In the final step, group make a choice. After several alternatives are evaluated, the one that is considered acceptable is chosen.

In our tourist's group knowledge representation we assume that all group's variables have influence on the decision making process of a tourist destination and how e-wom influences tourist's decision making process.

\section{The Role of E-Wom in Tourist's Group Knowledge}

Tourism has become the world's largest industry and its growth shows a consistent year to year increase. The World Tourism Organization (WTO, World Tourism Organization, 2012) predicts that by 2020 tourist arrivals around the world would increase over $200 \%$. Tourism has become a highly competitive business for tourism destination over the world.

Competitive advantage is no longer natural, but increasingly driven by science, information technology and innovation. The Internet is already the primary sources of tourist destination information for travellers. About $95 \%$ of Web users use the Internet to gather travel related information and about $93 \%$ indicate that they visited tourism Web sites when planning for vacations. The number of people turning to the Internet for vacation and travel planning has increased more than 300\% over the past five years (WTO, World Tourism Organization, 2012). A variety of recent studies (e.g., by the European Travel Commission, 2011) revealed that the Web is nowadays already the primary source of information for people when searching or booking suitable travel destinations.

Since the special characteristics of Internet in terms of ease of knowledge sharing and fast messaging, web-based technologies are giving new meaning to word of mouth modalities. It includes informal communications directed at consumers through Internet-based technology related to the usage or characteristics of particular goods and services or their sellers (Livtin et al., 2008; Strielkowski et al., 2012). It is possible to consider e-word-of-mouth communication (e-wom) as different to traditional word of mouth 
communication (wom) because it reaches audiences of unprecedented scale and allows organizations to monitor and control their operations (products, services, events).

Since the effects of online reviews are pronounced for experiential than for utilitarian products (Pan \& Zhang, 2011) and the intangible nature of tourism products before the effective consumption (Pantano et al., 2011; Litvin et al. 2008; Yoo \& Gretzel, 2011), we believe that especially tourism sectors is forced by social networks to define new strategies for replying to the market trends.

Many tourists consult online reviews before choosing a hotel, and they might play an important role especially for the less-known brand hotels (Vermeulen \& Seegers, 2009). In fact, there is an effective causal relationship between online tourists' reviews and online hotel room sales (Ye et al., 2011). In particular, a tourist' review reduces both the cognitive load and the risk employed during the decision making process, supporting traveller to make a better choice (Pantano et al., 2011).

In this scenario, the impact of e-wom on tourist' decision making is important, especially in the hospitality industry. When tourists articulate comments and review on social network, inexperienced tourists gain an opportunity to enhance their understanding of tangible factors and to reduce their risk in terms of intangibles. Making a decision to a tourist destination involves significant risk, which may eventually lead tourists to become dependent on the interpersonal influence on a social network (Pantano et al., 2011).

E-wom is capable of influencing destination's image by providing positive or negative comments related to tourists' experiences (Litvin et al., 2008). In fact, online suggestions/comments/reviews are capable of improving the tourist perception of the travel product among potential users (Ye et al., 2011), thus online suggestions/comments provided by other users has a significant effect on the online sales of tourism products (i.e. online rooms booking) (Ye et al., 2011). As a consequence, consumers are prompt to use the social media for searching information on possible tourism destinations, visualizing images, access to tourist's previous experiences, in order to gain the sufficient elements for the best choice (Sicilia \& Ruiz, 2010).

To investigate the specifics of e-wom behaviours, researchers studying online consumer psychology have focused on how e-wom influences tourist's decision making processes. In our prospective, we ask how e-wom influences tourist's group decision making processes and how cab be integrated in our representation of consumer's group knowledge. In particular, we ask three important research questions regarding the role of e-wom.

RQ1: E-word of mouth communication can be considered a group's variable. RQ2: E-word of mouth communication will have influence on tourist's group decision making process.

RQ3: E-word of mouth communication can be integrated in our representation of tourist's group knowledge. 
Figure 1 illustrates our hypothetical representation of tourist's group knowledge.

Figure 1. A Representation of Tourist's Group Knowledge

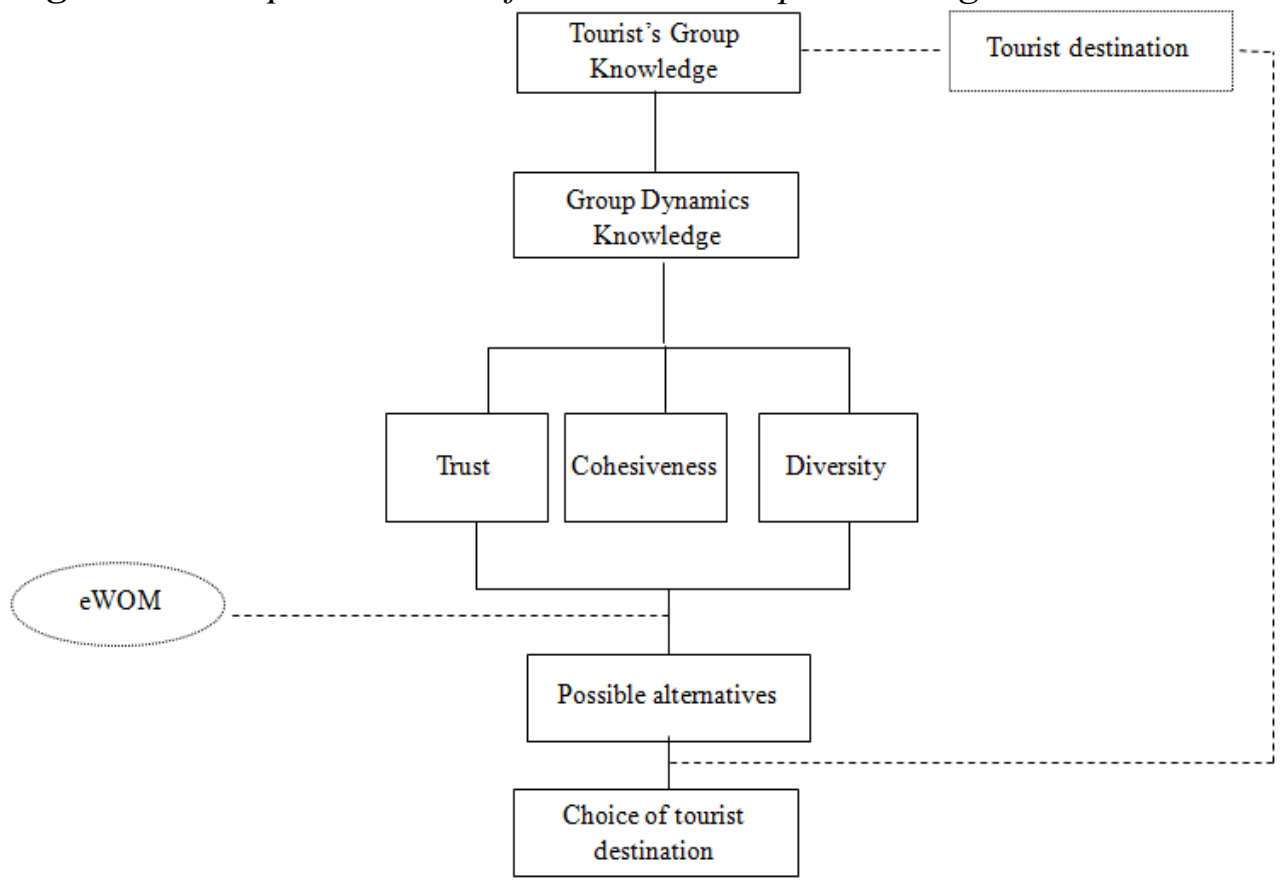

\section{Conclusion}

We recapitulate that the representation we propose will accomplish one important goal with respect to tourist knowledge. Using the group's theory, and guided by the theoretical approaches from related research in tourist behaviour and on-line communication, this paper provides an analytical framework to explore the tourist's group knowledge investigating the influence of group variables and the role of e-wom on decision making process.

Our study shows that there are some important potential applications of tourist's group knowledge representation in the study of tourist behaviour, with an outline of the major theoretical approaches to these applications. Gaining and utilising consistent knowledge by tourists is not a simple or straightforward task. It is a highly involved and multidimensional process, which is seldom complete or errorless. Furthermore, different elements of this process may separately or jointly exert varying, and sometimes, conflicting influences on the normally complicated decision making process for tourists.

Practitioners can use this conceptual representation to evaluate knowledge of a group of tourists and better target future knowledge management interventions towards those groups most likely to benefit. 
The findings focus especially on the role of e-wom on both attitude and behavioural intention. As a consequence, these results might be considered as one of the emerging attempts to investigate empirically tourist' acceptance of computer-mediated communication in social networks as informative sources.

These conclusions are relevant for both researchers and hospitality managers. On the one hand, they contribute to deepening the scientific debate on the tourist's behavioural intention. On the other, the findings provide support to the marketing and communication strategies of hospitality marketers who have to develop, monitor and manage their products, services, events, and brand in a practically infinite virtual domain.

In this scenario, hospitality marketers would run their marketing and communication activities splitting their time and financial resources among different social media applications in different ways. In fact, tourists use social media applications according to different modalities and behave towards them during the decisional process, as well and in the post-travel (post-consumption) phase. Thus hospitality marketers should provide incentives to their customers to post online reviews, videos and photos.

To understand interactions within a group of tourists as a source of knowledge can help tourism operators also attain a competitive advantage in product and service innovation. Therefore, the added value consists of conceptual and practical issues, which can support both tourism operators and scientific community to exploit new approaches in order to disseminate tourism destinations in an innovative way.

\section{Limitation and Future Research Directions}

This type of research, which provides a rich understanding of the tourist's group, are nonetheless expensive due to high cost of training of employees and salespeople. To understand the group's variables and their influence on a group decision making process, expensive ethnographic and qualitative research techniques are necessary. Anyway, given the nascent nature of the study phenomenon, there may be many exciting opportunities that lay ahead for new research. This study contributes to the development of a program of research on tourist's group knowledge.

Moreover, the research does not focus on a specific tourist's destinations, thus the presence of different destinations may affect consumers in different way, according to their involvement towards to a particular destination. Future research might focus on extending our model to encompass other theoretical constructs inserting new variables over enjoyment and e-wom, such as experience, gender diversity or group's dynamics. In addition, future research should investigate which are the social networks more used for the choice of tourist destination. 


\section{References}

Alavi, M. \& Leidner, D.E. (2001). 'Knowledge management and knowledge management systems: Conceptual foundations and research issues'. MIS Quarterly, 25 (1): 107-136.

Boyd, D. \& Ellison, N. (2007). 'Social network sites, definition, history, and scholarship'. Journal of Computer-Mediated Communication, 13: 1-9.

Buhalis, D. \& Law, R. (2008). 'Progress in information technology and tourism management, 20 years on and 10 years after the Internet - The state of eTourism research'. Tourism Management, 29 (4): 609-623.

Bunderson, J.S. \& Sutcliffe, K.M. (2002). 'Comparing alternative conceptualizations of functional diversity in management teams: Process and performance effects', Academy of Management Journal, 45: 875-893.

Cheng, H. (2010). 'Seeking knowledge or gaining legitimacy? Role of social networks on new practice adoption by OEM suppliers'. Journal of Business Research, 63 (8): 824-831.

Davis, J.H., Schoorman, F.D., Mayer, R.C. \& Tan, H.H. (2000). 'The trusted general manager and business unit performance: Empirical evidence of a competitive advantage'. Strategic Management Journal, 21: 563-576.

de Valck, K., van Bruggen, G. \& Wierenga, G. (2009). 'Virtual communities: A marketing perspective'. Decision Support Systems, 47 (3): 185-203.

Dellarocas, C. (2003). 'The Digitization of Word of Mouth, Promise and Challenges of Online Feedback Mechanisms'. Management Science, 49 (10): 1407-1424.

Dirks, K.T. \& Ferrin, D.L. (2001). 'The role of trust in organizational settings'. Organization Science, 12 (4): 450-467.

European Travel Commission (2011). http://www.etc-corporate.org/. Accessed the 20 April 2011, at 12.20.

Franco, M., Di Virgilio, F. \& Di Pietro, L. (2010). 'A conceptual representation of consumer's group knowledge and the possible role of new technologies'. International Journal of Digital Content, Technology and its Applications, 7 (4): $11-22$.

Grover, V. \& Davenport, T.H. (2001). 'General perspectives on knowledge management: Fostering a research agenda'. Journal of Management Information Systems, 18 (1): 5-21.

Gruenfeld, D.H., Mannix, E.A., Williams, K.Y. \& Neale, M.A. (1996). 'Group composition and decision making: How member familiarity and information distribution affect process and performance'. Organizational Behavior and Human Decision Processes, 67 (1): 1-15.

Kracht, J. \& Wang, Y. (2009). 'Examining the tourism distribution channel: evolution and transformation'. International Journal of Contemporary Hospitality Management, 22 (5): 736-757.

Jehn, K.A. \& Mannix, E.A. (2001). 'The Dynamic Nature of Conflict: Longitudinal Study of Intragroup Conflict and Group Performance'. Academy of Management Journal, 44: 238-251.

Jehn, K. \& Bezrukova, K. (2004). 'A field study of group diversity, group context, and performance'. Journal of Organizational Behaviour, 25 (6): 703-729.

Lawrence, B.S. (1997). 'The black box of organizational demography'. Organization Science, 8: 1-22. 
Levin, D.Z. (1999). 'Transferring knowledge within the organization in the Rend arena'. Unpublished doctoral dissertation, North-western University, Evanston.

Litvin, S.W., Goldsmith, R.E. \& Pan, B. (2008). 'Electronic word-of-mouth in hospitality and tourism management'. Tourism Management, 29 (3): 458-468.

Mayer, R.C., Davis, J.H. \& Schoorman, F.D. (1995). 'An integrative model of organizational trust'. Academy of Management Review, 20: 709-734.

Maznevski, M.L. (1994). 'Understanding our differences: performance in decisionmaking groups with diverse members'. Human Relations, 47 (5): 531-32.

Menkhoff, T., Yian, T.T., Wah, C.Y. \& Kee, W.Y. (2011). 'Engaging knowledge management learners through web-based ICT: an empirical study'. VINE, 41 (2): 132-151.

Ogunseye, S.O., Adetiloye, P.K., Idowu, S.O., Folorunso, O. \& Akinwale, A.T. (2011). 'Harvesting knowledge from computer mediated social networks'. VINE, 41 (3): 252-264.

O'Reilly, T. (2005). What Is Web 2.0: Design Patterns and Business Models for the Next Generation of Software. http://www.oreillynet.com/pub/a/oreilly/tim/news/ 2005/. Accessed the 18 July 2005, at 16.30 .

Pan, Y. \& Zhang, J.Q. (2011). Born unequal: a study of the helpfulness of usergenerated product reviews. Journal of Retailing, 87 (4): 598-612.

Pantano, E., Servidio, R. \& Viassone, M. (2011). 'An exploratory study of the touristcomputer interaction: the role of web site usability on hotel quality perception'. International Journal of Digital Content Technology and its Application, 5 (5): 208-216.

Pantano, E. \& Servidio, R. (2011). 'An exploratory study of the role of pervasive environments for promotion of tourism destinations'. Journal of Hospitality and Tourism Technology, 2 (1): 50-65.

Papanis, E. \& Kitrinou, E. (2011). 'The Role of Alternative Types of Tourism and Ict Strategy for the Tourism Industry of Lesvos'. Tourismos, 6 (2).

Pelled, L., Eisenhardt, K. \& Xin, K. (1999). 'Exploring the black box: An analysis of work group diversity, conflict, and performance'. Administrative Science Quarterly, 44: 1-28.

Postmes, T., Spears, R. \& Cihangir, S. (2001). 'Quality of decision making and group norms'. Journal of personality and social psychology, 80 (6): 918 - 930.

Poston, R.S. \& Speier, C. (2005). 'Effective use of knowledge management systems: A process model of content ratings and credibility indicators'. MIS Quarterly, 29 (2): 221-244.

Rulke, D.L. \& Galaskiewicz, J. (2000). 'Distribution of Knowledge, Group Network Structure, and Group Performance'. Management Science, 46 (5): 612-625.

Schermerhorn, J.R., Hunt, J.G. \& Osborn, R.N. (2008). Organizational Behavior, 8th Ed., John Wiley e Sons Inc, New York.

Shaw, J.B. \& Barret-Power. E. (1998). 'The effects of Diversity on Small Work Group Processes and Performance'. Human Relations, 51: 1307-1325.

Sicilia, M. \& Ruiz, S. (2010). 'The Effect of Web-Based Information Availability on Consumers' Processing and Attitudes'. Journal of Interactive Marketing, 24: 3141.

Spreitzer, G.M. \& Mishra, A. K. (2002). 'To Stay or to Go: Voluntary Survivor Turnover Following an Organizational Downsizing'. Journal of Organizational Behavior, 23 (6): 797-729.

Stasser, G., Vaughan, S.I. \& Stewart, D.D. (2000). 'Pooling unshared information: the benefits of knowing how access to information is distributed among group 
members'. Organizational Behaviour and Human Decision Processes, 82 (1): 102-116.

Stewart, G.L., Manz, C.C. \& Sims, H.P. (1999). Team work and group dynamics. John Wiley and Sons, USA.

Strielkowski, W., Riganti, P. \& Wang, J. (2012). 'Tourism, Cultural Heritage and EServices: Using Focus Groups to Assess Consumer Preferences'. Tourismos, 7 (1).

Tanriverdi, H. (2005). 'Information technology relatedness, knowledge management capability, and performance of multibusiness firms'. MIS Quarterly, 29 (2): 311334.

Vermeulen, I.E. \& Seegers, D. (2009). 'Tried and tested: the impact of online hotel reviews on consumer consideration'. Tourism Management, 30: 123-127.

Vuori, V. \& Okkonen, J. (2012). 'Refining information and knowledge by social media applications: Adding value by insight'. VINE, 42 (1): 117 - 128.

Wasko, M.M. \& Faraj, S. (2005). 'Why should I share? Examining social capital and knowledge contribution in electronic networks of practice'. MIS Quarterly, 29 (1): 35-57.

West, M.A., Garrod, S. \& Carletta, J. (1997). Group decision-making and effectiveness: unexplored boundaries, in Cooper, C. L. \& Jackson, S. E. (Eds), Creating tomorrow's organizations a handbook for future research in organizational behavior, John Wiley and Sons, USA.

World Tourism Organization, (2012). http://www2.unwto.org/. Accesseed the 30 November 2012, at 11.15.

Ye, Q., Law, R., Gu, B. \& Chen, W. (2011). 'The influence of user-generated content on traveller behavior: An empirical investigation on the effects of e-word-of mouth to hotel online booking'. Computers in Human Behavior, Vol. 27, No. 2, pp. 634-639.

Yoo, K.H. \& Gretzel, U. (2011). 'Influence of personality on travel-related consumergenerated media creation'. Computers in Human Behaviour, 27: 609-621.

Yoon, C., Cole, C.A. \& Lee, M.P. (2009). 'Consumer decision making and aging: Current knowledge and future directions'. Journal of Consumer Psychology, 19: $2-16$.

Zaheer, A., \& Venkatraman, N., (1995). 'Relational governance as an interorganizational strategy: an empirical test of the role of trust in economic exchange'. Strategic Management Journal, 16 (5): 373-92. 
